Article

\title{
Densities of Agrilus auroguttatus and Other Borers in California and Arizona Oaks
}

\section{Laurel J. Haavik $^{1, \dagger}, *$, Tom W. Coleman ${ }^{2}$, Mary Louise Flint ${ }^{1}$, Robert C. Venette ${ }^{3}$ and Steven J. Seybold ${ }^{4}$}

1 Department of Entomology, University of California-Davis, One Shields Avenue, Davis, CA 95616, USA; E-Mail: mlflint@ucdavis.edu

2 USDA Forest Service, Forest Health Protection, 602 S. Tippecanoe Avenue, San Bernardino, CA 92408, USA; E-Mail: twcoleman@fs.fed.us

3 USDA Forest Service, Northern Research Station, 1561 Lindig Street, St. Paul, MN 55108, USA; E-Mail: rvenette@fs.fed.us

4 USDA Forest Service, Pacific Southwest Research Station, HDH001 Orchard Park Drive, Rm 116, Davis, CA 95616, USA; E-Mail: sjseybold59@gmail.com

$\dagger$ Current address: Great Lakes Forestry Centre, 1219 Queen Street East, Sault Ste. Marie, ON P6A 2E5, Canada

* Author to whom correspondence should be addressed; E-Mail: ljhaavik@gmail.com; Tel.: +1-705-541-5636; Fax: +1-705-541-5700.

Received: 6 December 2013; in revised form: 7 March 2014 / Accepted: 11 March 2014 / Published: 21 March 2014

\begin{abstract}
We investigated within-tree population density of a new invasive species in southern California, the goldspotted oak borer, Agrilus auroguttatus Schaeffer (Coleoptera: Buprestidae), with respect to host species and the community of other borers present. We measured emergence hole densities of $A$. auroguttatus and other borers on the lower stem (bole) of naïve oaks at 18 sites in southern California and on co-evolved oaks at seven sites in southeastern Arizona. We sampled recently dead oaks in an effort to quantify the community of primary and secondary borers associated with mortality — species that were likely to interact with $A$. auroguttatus. Red oaks (Section Lobatae) produced greater densities of $A$. auroguttatus than white oaks (Section Quercus). On red oaks, A. auroguttatus significantly outnumbered native borers in California (mean \pm SE of $9.6 \pm 0.7$ versus $4.5 \pm 0.6$ emergence holes per $0.09 \mathrm{~m}^{2}$ of bark surface), yet this was not the case in Arizona $\left(0.9 \pm 0.2\right.$ versus $1.1 \pm 0.2$ emergence holes per $\left.0.09 \mathrm{~m}^{2}\right)$. In California, a species that is
\end{abstract}


taxonomically intermediate between red and white oaks, Quercus chrysolepis (Section Protobalanus), exhibited similar A. auroguttatus emergence densities compared with a co-occurring red oak, Q. kelloggii. As an invasive species in California, A. auroguttatus may affect the community of native borers (mainly Buprestidae and Cerambycidae) that feed on the lower boles of oaks, although it remains unclear whether its impact will be positive or negative.

Keywords: host suitability; invasive species; oak ecosystems; phloem and wood borer; population dynamics

\section{Introduction}

The goldspotted oak borer, Agrilus auroguttatus Schaeffer (Coleoptera: Buprestidae), is a new pest of oaks in southern California (CA) [1]. It was first collected in CA in 2004 [2]. Collection records throughout the 20th century indicate that $A$. auroguttatus is native to mountain ranges in southeastern Arizona (AZ) [3]. Current genetic evidence is consistent with AZ populations as the probable source for CA populations [4]. Prior to its discovery in CA, little was known about this beetle's biology and ecology. Knowledge of the effect of host species $[5,6]$ and interactions with the community of other borers present within its native and introduced ranges are important for understanding the invasion biology of $A$. auroguttatus.

In their new ecosystems, invasive species populations can reach damaging levels because new habitats may lack important natural enemies (e.g., enemy release, [7]), or co-evolved resistance mechanisms among new host plants (e.g., biotic resistance, [8]). Consequently, invasive insects can have direct effects on populations of these naïve host plants and indirect effects on native populations of specialist herbivores that may share hosts with the invader [9-11]. Comparing the biology and ecology of invasive species in their new habitats with those in their native ranges can further understanding of invasion biology and may help to identify possible management techniques for invasive pests.

Direct comparisons of $A$. auroguttatus population densities on species from the red (Section Lobatae) and white oak (Section Quercus) groups in CA or AZ have not been made among individual trees of similar physiological status. Such comparisons may confirm whether red oaks are more preferable or suitable hosts than white oaks for A. auroguttatus. Thus far, extensive mortality (approx. 25,000 dead trees) in southern CA has occurred primarily among two species in the red oak group: CA black oak, Quercus kelloggii Newb., and coast live oak, Q. agrifolia Née [12]. Known host species of A. auroguttatus in AZ (also in Section Lobatae) include Emory oak, Q. emoryi Torrey, and silverleaf oak, Q. hypoleucoides A. Camus [3]. In CA, A. auroguttatus also colonizes the taxonomically intermediate species canyon live oak, Q. chrysolepis Liebm. (Section Protobalanus) and Engelmann oak, $Q$. engelmannii Greene, from the white oak group, although the latter is colonized at very low densities [13,14]. There have been no observations of A. auroguttatus on Arizona white oak, Q. arizonica L. (Section Quercus), which co-occurs with its red oak hosts in AZ [3,13]. 
Agrilus auroguttatus is the primary biotic agent causing tree mortality in southern CA oak forests [13], but its influence on native borer populations in the main stem of oaks remains largely unknown. Comparisons of $A$. auroguttatus population densities to densities of other borers may be a first step towards determining borer community interactions in oak ecosystems. A suite of native oak insects feed in subcortical tissues within the main stem (bole) of southern CA oaks [15-17]. Records of oak-feeding insects in southeastern $\mathrm{AZ}$ are more limited [16,18].

Our objective was to investigate within-tree densities of $A$. auroguttatus in its introduced and native ranges with respect to host species and the community of other borers present. We compared the density of emergence holes from A. auroguttatus and other borers on different species of recently dead oaks among several sites in CA and AZ. Our study focused on the community of borers in the lower bole because $A$. auroguttatus occurs most frequently in this portion of the stem [19]. We hypothesized that: (1) species in the red oak group would be better hosts for A. auroguttatus, and thus produce higher emergence densities than co-occurring white oak species; and (2) A. auroguttatus would outnumber other borers in its introduced range (CA), but not in its native range (AZ).

\section{Materials and Methods}

\subsection{Study Sites: Southern California}

Eighteen study sites were selected in the current zone of A. auroguttatus infestation within the Cleveland National Forest and one site was selected outside the currently infested zone (Warner Springs) in southern CA (Table 1; infestation zone as of 2010 in [3]). Sites were distributed approximately evenly throughout the public forested lands of the Descanso Ranger District to evaluate variation in borer populations throughout the National Forest. Ten sites were Q. agrifolia-dominant oak woodlands (900-1500 $\mathrm{m}$ in elevation) and the remaining nine sites were mixed Q. kelloggii-pine forests (mostly Pinus jeffreyi Grev. \& Balf.; 1500-1800 $\mathrm{m}$ in elevation). We searched for, but could not find, sites where both of these red oak species occurred and A. auroguttatus was present. Thus, statistical comparisons of borer density between these two host species were not possible because the effect of host species on $A$. auroguttatus density was confounded with the effects of location and elevation. Comparisons of $A$. auroguttatus emergence holes could only be made between host species pairs at two sites (Roberts' Ranch and Thing Valley), where two red oak/non-red oak species pairs occurred (Table 1).

Climate in the Descanso Ranger District is Mediterranean with hot summers (mean August and January maximum temperatures: $30^{\circ} \mathrm{C}$ and $14{ }^{\circ} \mathrm{C}$, respectively [20]) [21]. The majority of precipitation occurs in the winter (total annual precipitation is $53 \mathrm{~cm}$ [20]). Soils are rocky, well-drained sandy loams above decomposed granitic bedrock [21].

\subsection{Study Sites: Southeastern Arizona}

Seven study sites were selected within the Coronado National Forest in southeastern AZ where oak mortality was identified during previous surveys [13]. Sites with $Q$. emoryi were oak woodlands (1400-1700 m elevation) and sites with $Q$. hypoleuocides and $Q$. arizonica were mixed oak-pine forests that also contained Juniperus deppeana, Pinus spp., Platanus racemosa Nutt., and Acer spp. 
(1500-1750 m elevation) (Table 1). It was difficult to find sites in southeastern AZ with both co-occurring oak species and with evidence of A. auroguttatus infestation. Only one study site, Cochise Stronghold Campground, contained all three oak species. Borer densities were also compared between Q. arizonica and Q. hypoleucoides at Carr and Miller Canyons. At all other sites, borer emergence holes were counted on only one oak species.

Table 1. Site information, tree sample sizes (n) and tree size (diameter at breast height, $\mathrm{DBH})$ by host species and taxonomic section.

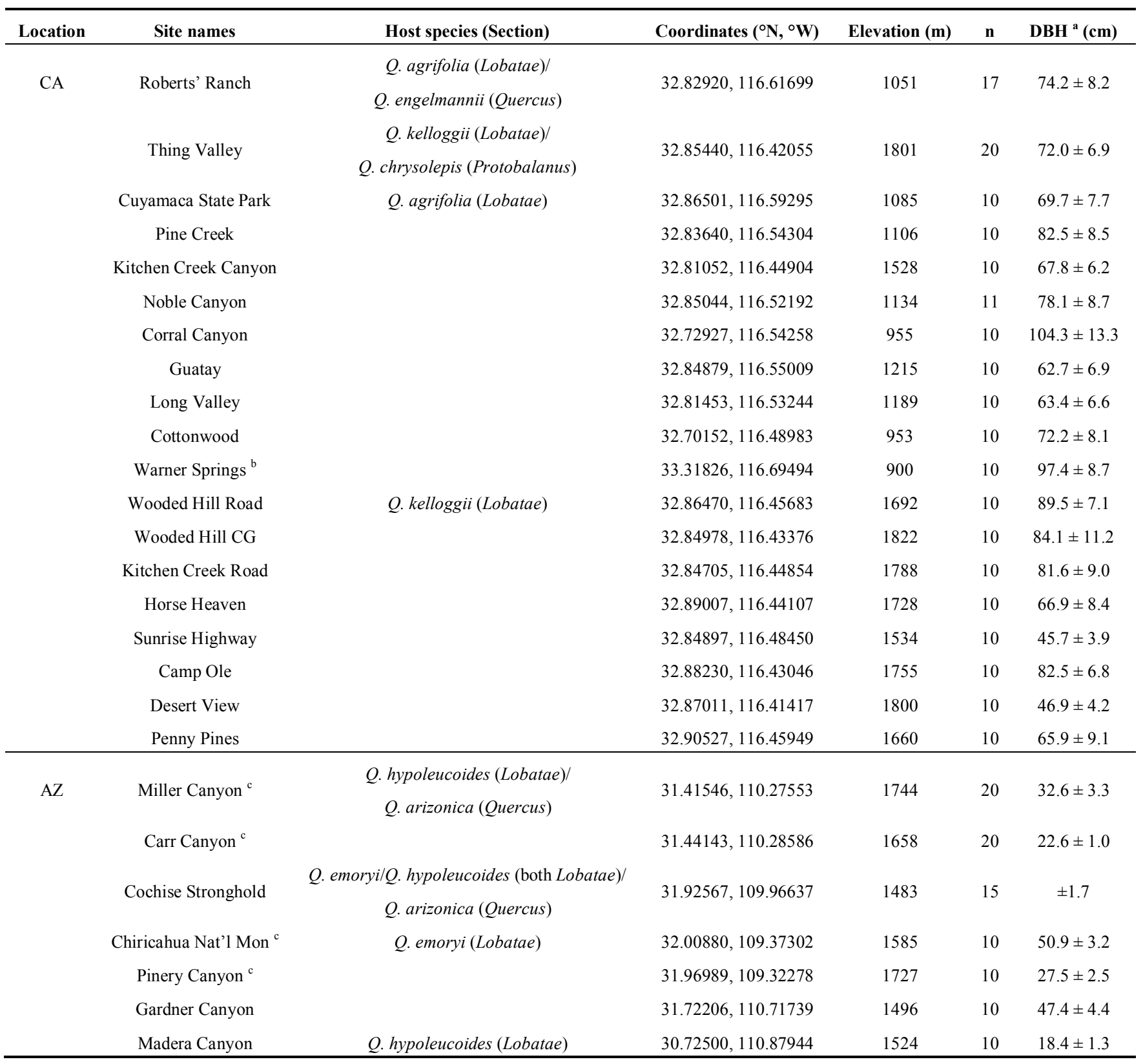

${ }^{\mathrm{a}}$ Mean $\pm \mathrm{SE}$, measured at $1.4 \mathrm{~m}$ from the ground; ${ }^{\mathrm{b}}$ Site outside current zone of A. auroguttatus infestation in southern California; ${ }^{\mathrm{c}}$ Sites affected by the June 2011 wildfire.

AZ study sites were sampled partially during March 2011 and sampling was completed during February 2012. Wildfires affected the Chiricahua National Monument, Pinery, Miller and Carr Canyons in June 2011 [22]. Borer emergence holes were counted on three dead Q. hypoleucoides before the fire and seven after the fire at Miller Canyon as well as four $Q$. emoryi before the fire and 
six after the fire at Pinery Canyon. Density of emergence holes did not differ significantly between dead trees sampled before vs. after the fire at either site (pooled variance $t$-tests, A. auroguttatus: $t=1.23$ and $0.26, \mathrm{df}=2.01$ and $4.94, p=0.34$ and 0.80 for Miller and Pinery Canyons, respectively; and other borers: $t=1.15$ and $0.30, \mathrm{df}=2.02$ and 4.62, $p=0.37$ and 0.77 for Miller and Pinery Canyons, respectively).

Climate in the Coronado National Forest in southeastern Arizona is semi-arid. Total annual precipitation varies throughout these mountain ranges from $34-58 \mathrm{~cm}$, and mean August and January maximum temperatures are $32{ }^{\circ} \mathrm{C}$ and $16{ }^{\circ} \mathrm{C}$, respectively [20]. Soils are rocky and classified mostly as Aridisols, although some are Mollisols or Entisols [23].

\subsection{Evaluation of Borer Density}

Cumulative borer emergence was estimated on the lower boles $(\leq 1.52 \mathrm{~m})$ of the first 10 , or as many as we could find if fewer than 10, recently dead (died within the last 1-3 y, borer emergence holes were still clearly defined, and at least half of the bark on the lower bole remained) oaks encountered at all CA and AZ sites. A total of 91 Q. kelloggii (nine sites); 99 Q. agrifolia (10 sites); 10 Q. chrysolepis (one site); 7 Q. engelmannii (one site); 40 Q. emoryi (four sites); 33 Q. hypoleucoides (four sites); and 23 Q. arizonica (three sites) were sampled for the entire study. We did not sample living trees because our goal was to obtain a final measure of borer density from trees that were not likely to produce additional generations of borers. While some borer species may feed on dead and decaying wood, it was assumed that including only standing, recently-dead trees would limit the sample to those species that were primary or secondary mortality agents feeding on dying vascular tissue in weakened or stressed hosts. These species were most likely to interact with A. auroguttatus (as opposed to species that feed on dead or decaying wood).

All emergence holes were counted within a $0.09 \mathrm{~m}^{2}\left(1 \mathrm{ft}^{2}\right)$ sampling window (cardboard frame) at three arbitrary locations on the lower bole $(\leq 1.52 \mathrm{~m})$ of each oak tree, where A. auroguttatus emergence holes are dispersed randomly and occur most frequently [19]. Sampling efforts were focused on the lower bole because the goal was to estimate densities of $A$. auroguttatus where it was most likely to be present in relation to other borers.

Emergence (and by assumption, development) by A. auroguttatus or other borers was determined according to emergence hole size and shape [14]. Agrilus auroguttatus emergence holes were D-shaped and about $4 \mathrm{~mm}$ wide [14,24]. The size and shape of these holes are uniquely diagnostic for this species among the community of subcortical insects on California oaks. Emergence holes from flatheaded borers (Buprestidae) other than A. auroguttatus (Chrysobothris spp.) were oblong or crescent-shaped and 5-13 $\mathrm{mm}$ wide; roundheaded borer (Cerambycidae) (Rosalia funebris (Motschulsky), Xylotrechus nauticus (Mannerheim) or Neoclytus conjunctus (LeConte)) emergence holes were round or oblong and 6-10 mm wide; false powderpost beetles (Bostrichidae) (Scobicia declivis (LeConte)) entrance and emergence holes were perfectly round and $4 \mathrm{~mm}$ in diameter (the same size as $A$. auroguttatus only perfectly round); bark and ambrosia beetles (Curculionidae: Scolytinae) (Pseudopityophthorus spp. or Monarthrum spp.) entrance and emergence holes were also round, but $\leq 2 \mathrm{~mm}$ in diameter; clearwing borer (Lepidoptera: Sessiidae) (Synanthedon resplendens (Edwards)) emergence holes were round and 5-6 $\mathrm{mm}$ in diameter and found exclusively in bark cracks 
near deteriorated bark and phloem; and carpenterworm (Lepidoptera: Cossidae) (Prionoxystus robiniae Peck) emergence holes were oval often with jagged edges and 10-20 mm wide [15-18,25,26]. Emergence holes were categorized as "unknown" if they could not be identified to insect family or if bark had deteriorated at all since the insect emerged to the extent that the hole's original shape was somewhat unclear. There was overlap in the shape and size of emergence holes for Chrysobothris spp. and Cerambycidae (particularly $X$. nauticus), so counts were grouped from both taxa (bup + cer) for analyses.

\subsection{Data Analyses}

All statistical analyses were conducted within the R statistical environment, version 2.15.0 [27]. We used pooled variance $t$-tests or analyses of variance (ANOVA) to test for the effect of oak species on density of $A$. auroguttatus emergence holes. We used ANOVA to test for the effect of borer group on density of emergence holes followed by Tukey's HSD ad-hoc tests, applied separately to each oak species at CA sites where two oak species co-occurred.

We applied Pearson's correlations to search for a relationship between density of emergence holes of $A$. auroguttatus and all other borer groups combined (on red oak species only), performed for each oak species (all sites combined), and separately by site. We used mixed effect linear models with restricted maximum likelihood estimation to compare number of A. auroguttatus emergence holes against that of all other borer groups combined, tested separately by host species for red oaks. Borer type was a fixed effect and site was a random effect.

For all linear models, model checks included the Shapiro-Wilk normality test [28], standardized residual plots, and normal probability plots. Data were transformed to meet model assumptions (adding 0.5 to original values and then applying the Box-Cox method [29] to determine appropriate transformations, used for all response data except for $t$-tests in Figure 1A,B). If data could not be transformed to meet parametric assumptions (for effect of borer group on emergence holes for Q. kelloggii at Thing Valley and $Q$. agrifolia at Warner Springs, Figure 2A,E, respectively), we applied ANOVA to ranks. We present results from ANOVA on ranks (Figure 2A,E) as means with standard errors for visual comparisons with corresponding parametric models of different oak species. Statistical significance was set at $p<0.05$, all means in graphs are untransformed values, and errors are one standard error from the mean.

\section{Results}

Density of $A$. auroguttatus emergence holes differed significantly between some, but not other, oak species (Figure 1). At Roberts' Ranch in CA, A. auroguttatus density was greater on the red oak, $Q$. agrifolia, than on the co-occurring white oak, $Q$. engelmannii $(t=4.46 ; \mathrm{df}=9.15 ; p=0.002$; Figure 1A). Agrilus auroguttatus emergence holes were only found on two (mean of $1.0 \pm 0.6$ and $1.3 \pm 0.3$ per $0.09 \mathrm{~m}^{2}$ of bark on the two trees) of the seven $Q$. engelmannii sampled. At Thing Valley, Agrilus auroguttatus density did not differ significantly between $Q$. kelloggii and $Q$. chrysolepis $(t=0.68 ; \mathrm{df}=18.00 ; p=0.504 ;$ Figure 1B). Agrilus auroguttatus density also did not differ significantly between $Q$. emoryi, $Q$. hypoleucoides, or $Q$. arizonica at Cochise Stronghold in AZ $(F=0.77 ; \mathrm{df}=2,12 ; p=0.485 ;$ Figure $1 \mathrm{C})$. No A. auroguttatus emergence holes were found on 
Q. hypoleucoides or $Q$. arizonica at Cochise Stronghold. At Carr and Miller Canyons in AZ, A. auroguttatus density did not differ significantly between sites $(F=0.25 ; \mathrm{df}=1,36 ; p=0.624)$, but differed significantly by oak species $(F=21.66$; $\mathrm{df}=1,36 ; p<0.001$; Figure 1D). A. auroguttatus density on $Q$. hypoluecoides was very low at these two sites, but was significantly greater than on Q. arizonica where no holes were found.

Figure 1. Mean densities of $A$. auroguttatus emergence holes on lower boles of dead oaks at CA sites containing host species pairs $(\mathbf{A}, \mathbf{B})$ and at $\mathrm{AZ}$ sites with more than one co-occurring host species $(\mathbf{C}, \mathbf{D})$. Significant differences between species are denoted by *. Sample sizes are in parentheses following species names. Oaks in Section Lobatae are red symbols; Section Protobalanus are gray symbols; and Section Quercus are white symbols.

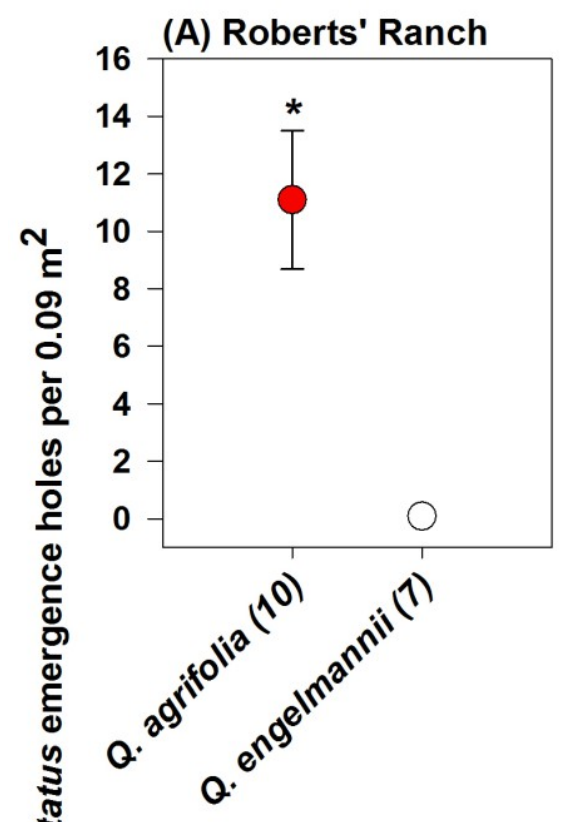

(B) Thing Valley

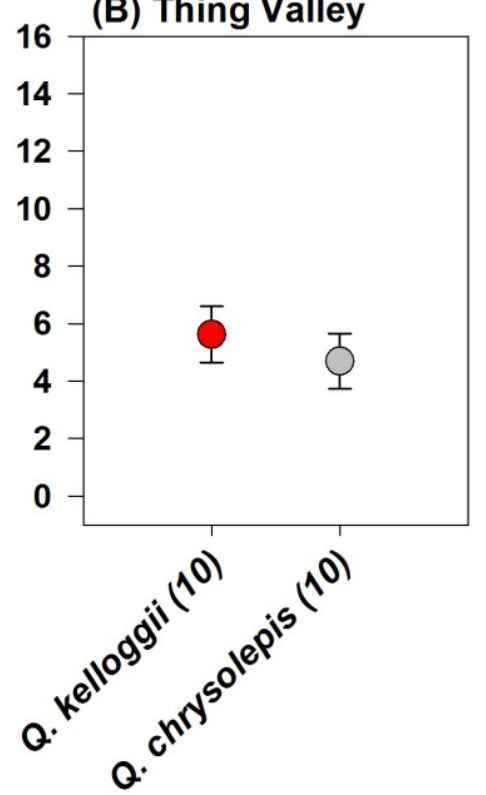

(C) Cochise Stronghold

(D) Carr and Miller Canyons
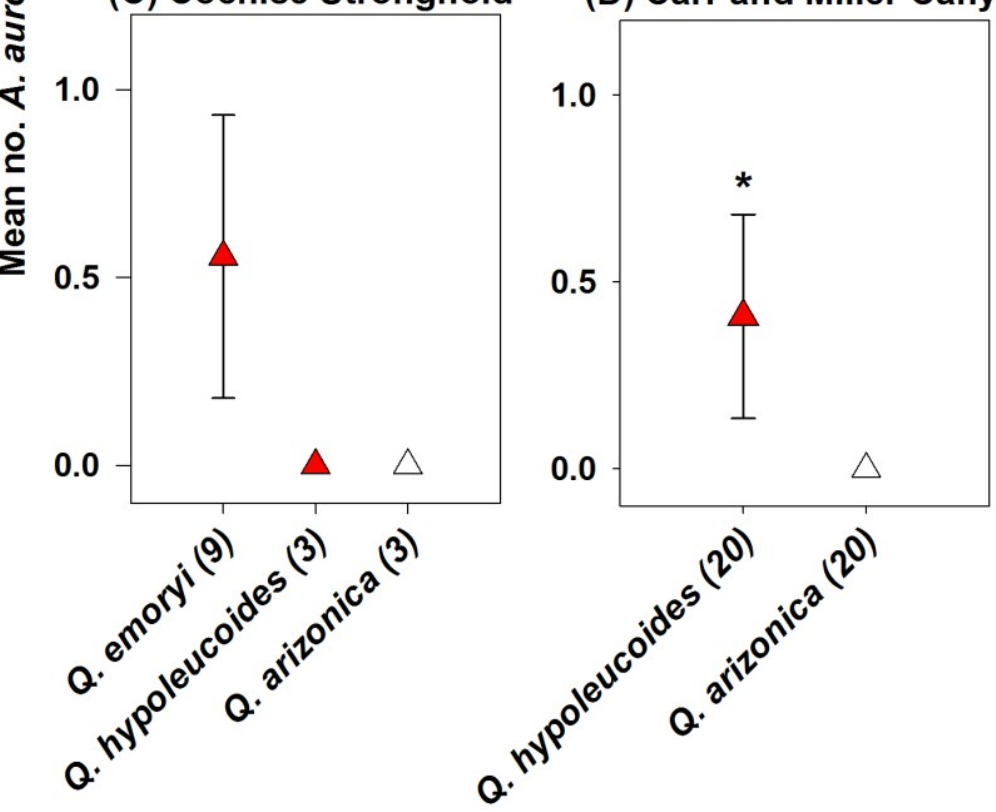

Host species 
Figure 2. Mean densities of emergence holes on the lower boles of dead oaks by borer group, tested separately by host species at CA sites containing host species pairs (A-D) and at Warner Springs, a site outside the current zone of A. auroguttatus infestation in CA (E). Letters above bars indicate significant differences according to Tukey's HSD; sample sizes are the same as corresponding species and sites for Figure 1; and $n=10$ trees (E). Oaks in Section Lobatae are red circles; Section Protobalanus are gray circles; and Section Quercus are white circles. X-axis categories are as follows: gsob = A. auroguttatus; bup + cer $=$ other Buprestidae combined with Cerambycidae; bos = Bostrichidae; cur $=$ Curculionidae $($ Scolytinae $)$; sess $=$ Sessiidae; and uk = unknown.

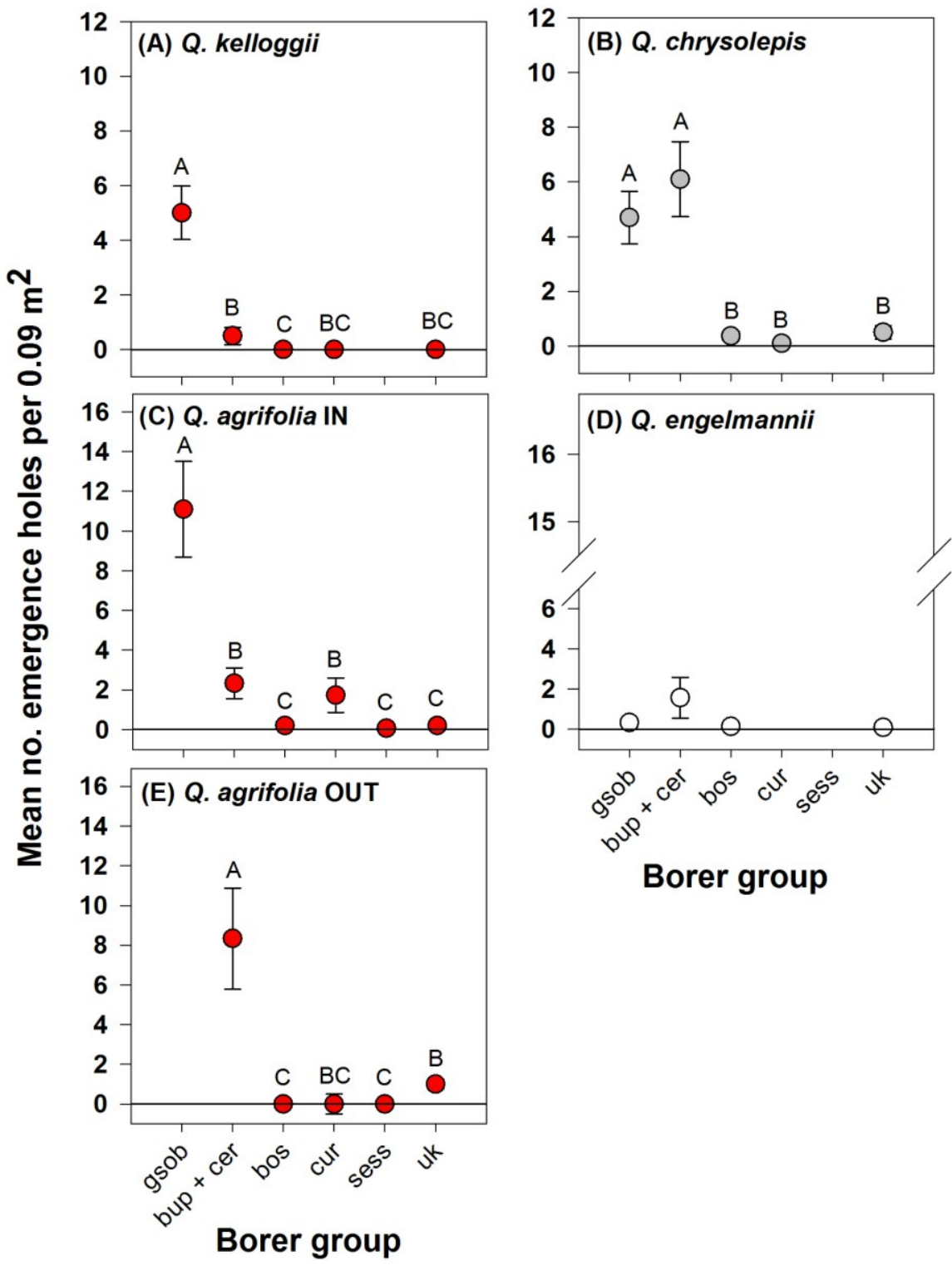

At sites in CA where pairs of oak species co-occurred, A. auroguttatus density was significantly greater than the density of other borer groups on the lower boles of $Q$. kelloggii $(F=27.47$; $\mathrm{df}=4,45$; $p<0.001$; Figure 2A) and $Q$. agrifolia within the current zone of infestation $(F=26.84 ; \mathrm{df}=5,54$; $p<0.001$; Figure 2C). Bup + cer density was also relatively high on the lower bole of CA oaks. Bup + cer and $A$. auroguttatus densities were greater than density of other borer groups on Q. chrysolepis $(F=30.51$; $\mathrm{df}=4,45 ; p<0.001$; Figure $2 \mathrm{~B})$. Bup + cer density was greater than 
densities of all other borers on $Q$. agrifolia outside the current zone of A. auroguttatus infestation $(F=36.65 ; \mathrm{df}=4,45 ; p<0.001 ;$ Figure $2 \mathrm{E})$. Emergence hole density was very low (mean of 1.0 per $0.09 \mathrm{~m}^{2}$ of bark, among all borer groups), and did not vary significantly by borer group on $Q$. engelmannii $(F=1.76 ; \mathrm{df}=3,24 ; p=0.182 ;$ Figure 2D).

On the lower bole, A. auroguttatus emergence was greater than that of all other borer species combined from red oak species across several sites in CA $(F=72.49$; df $=1,170 ; p<0.001$ and $F=70.46 ;$ df $=1,172 ; p<0.001$; Figure $3 \mathrm{~A}$ for $Q$. agrifolia and $Q$. kelloggii, respectively). Agrilus auroguttatus densities were not significantly different from those of all other borer species combined from red oak species in $\mathrm{AZ}(F=2.85 ; \mathrm{df}=1,82 ; p=0.095$ and $F=1.71 ; \mathrm{df}=1,61$; $p=0.196$; Figure 3B for $Q$. emoryi and $Q$. hypoleucoides, respectively).

Figure 3. Mean densities of emergence holes from A. auroguttatus compared to that of other borer species combined, tested separately for each host species in CA (A) and AZ (B). * indicates significantly greater value according to restricted maximum likelihood estimation for the fixed effect borer group in mixed models. Sample sizes are: 90 trees across nine sites (Q. agrifolia); 91 trees across nine sites (Q. kelloggii); 40 trees across four sites (Q. emoryi); and 33 trees across three sites (Q. hypoleucoides).

(A) California

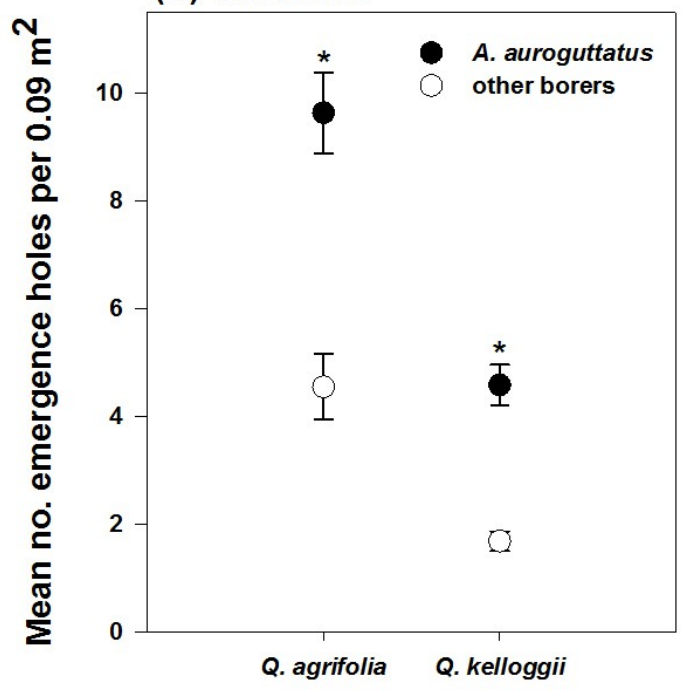

(B) Arizona

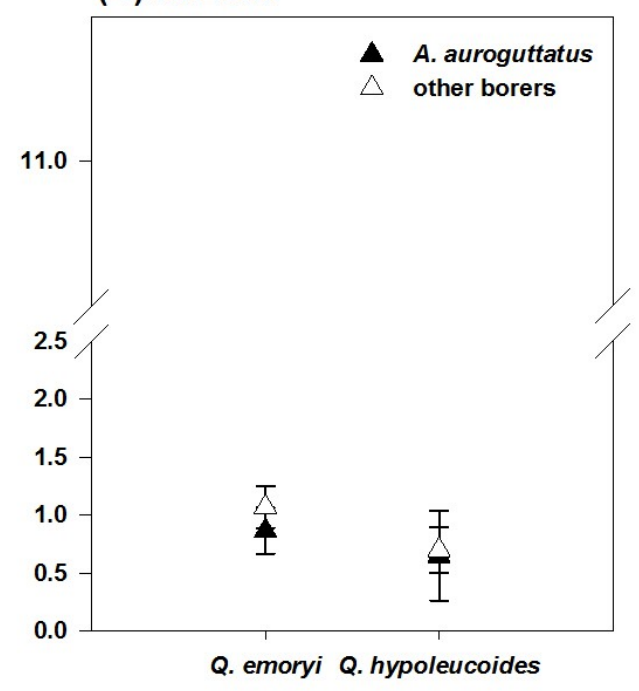

Host species

In general, emergence hole densities of $A$. auroguttatus were not significantly correlated with those of all other borer species combined among red oaks or at different sites. There were, however, three exceptions - emergence hole densities of A. auroguttatus and other borers were significantly positively correlated on $Q$. hypoleucoides among all sites $\left(\mathrm{r}_{\mathrm{p}}=0.521 ; p=0.003\right.$; not shown), on $Q$. kelloggii at Horse Heaven in CA $\left(\mathrm{r}_{\mathrm{p}}=0.849 ; p=0.002\right.$; not shown) and on $Q$. hypoleucoides at Miller Canyon in $\mathrm{AZ}\left(\mathrm{r}_{\mathrm{p}}=0.995 ; p<0.001 ;\right.$ not shown).

\section{Discussion}

The scarcity of sites in southern CA and southeastern AZ oak forests with co-occurring oak species where A. auroguttatus was also present prevented some direct comparisons among oak species. 
Although few direct comparisons were made, this study documents patterns of emergence from natural populations of $A$. auroguttatus that suggest red oaks are either more preferable or more suitable hosts than white oaks (i.e., $Q$. agrifolia versus $Q$. engelmannii and $Q$. hypoleucoides versus $Q$. arizonica; Figure 1A,D). A red oak, Q. kelloggii, may be equally preferable/suitable when compared with taxonomically intermediate $Q$. chrysolepis (Figure 1B). On native hosts at one site (Cochise Stronghold; Figure $1 \mathrm{C}$ ), densities of $A$. auroguttatus on red oaks were so low that they were not significantly different from a white oak, $Q$. arizonica. At this site, neither $Q$. hypoleucoides nor $Q$. arizonica showed evidence of $A$. auroguttatus colonization. The results of this study are consistent with previous observations, which report more frequent evidence of $A$. auroguttatus colonization on red oaks than white oaks $[3,13]$.

At the individual tree level, presence of $A$. auroguttatus in CA oak forests may result in lower densities of native buprestids and cerambycids on the lower boles of dying $Q$. agrifolia. At sites in CA with co-occurring oak species, A. auroguttatus was five times more abundant than all other borer groups on respective red oaks at each site ( $Q$. agrifolia and $Q$. kelloggii; Figure 2A,C). Other buprestids and cerambycids were also relatively abundant on three of the four oak species examined, and more abundant than all other borer groups on $Q$. agrifolia in the absence of A. auroguttatus (Figure 2E).

This study focused only on the lower portion of tree boles. Community interactions elsewhere in the bole, including species partitioning with height, were not measured and may be important. For example, in eastern North American oaks attacked by A. bilineatus, bark and ambrosia beetles were more prevalent in upper portions of boles [30]. In that study, buprestid and cerambycid densities remained relatively constant with bole height or were greatest on the lower bole and scolytine densities were greatest at $\sim 12.5 \mathrm{~m}$ above ground [30]. It is possible that A. auroguttatus may compete with native Buprestidae and Cerambycidae on the lower boles of dying Q. agrifolia, although data collected at different heights from trees of varying physiological conditions and from more sites outside the currently infested zone would be necessary to evaluate this hypothesis.

Across several sites throughout its invaded range in CA, and on both red oaks, A. auroguttatus outnumbered all species of native borers combined, yet this was not the case across sites in AZ (Figure 3). Across these sites, A. auroguttatus densities were similar to those of all other borer groups combined, which suggests that $A$. auroguttatus does not outnumber all other borer species in its native range as it does in its introduced range. Thus, although it is a primary mortality agent of red oaks in CA, it is more likely a secondary, though relatively frequent, mortality agent of red oaks in AZ oak forests.

The mean and range densities of $A$. auroguttatus that emerged from susceptible naïve hosts varied somewhat from those reported in other studies of Agrilus species on their respective naïve hosts (Table 2). The range that we reported for A. auroguttatus on $Q$. agrifolia was influenced by one tree that contained 50 emergence holes per $0.09 \mathrm{~m}^{2}$, the next greatest density was only 29 emergence holes per $0.09 \mathrm{~m}^{2}$. Similar to our observations of $A$. auroguttatus on co-evolved hosts, emergence densities of other Agrilus species were much lower on co-evolved than naïve hosts (Table 2). Many factors undoubtedly varied among the other studies referenced in Table 2 and ours. However, in those studies, trees had died recently or were moribund, and emergence densities reported were likely a result of the cumulative number of Agrilus beetles produced by dying trees. 
Table 2. Mean (range) emergence hole density of Agrilus spp. on co-evolved and naïve host trees reported from the literature and this study.

\begin{tabular}{|c|c|c|c|c|c|}
\hline Agrilus spp. & Host spp. & Relationship & Density per $0.09 \mathrm{~m}^{2}$ of bark & Density per $\mathrm{m}^{2}$ of bark & Reference \\
\hline \multirow{2}{*}{$\begin{array}{c}\text { A. auroguttatus Schaeffer, } \\
\text { goldspotted oak borer }\end{array}$} & Quercus agrifolia & naïve & $10(1-50)$ & $111(11-556)$ & This study ${ }^{a}$ \\
\hline & Q. kelloggii (both Fagaceae) & naïve & $5(0-16)$ & $56(0-178)$ & \\
\hline $\begin{array}{c}\text { A. planipennis Fairmaire, } \\
\text { emerald ash borer }\end{array}$ & $\begin{array}{l}\text { Fraxinus pennsylvanica, } \\
\text { F. americana (Oleaceae) }\end{array}$ & naïve & $8(2-15)$ & $89(17-170)$ & {$[31]^{b}$} \\
\hline $\begin{array}{l}\text { A. anxius Gory, bronze } \\
\text { birch borer }\end{array}$ & Betula pendula (Betulaceae) & naïve & $21(\mathrm{~N} / \mathrm{A})$ & $232(\mathrm{~N} / \mathrm{A})$ & {$[32]^{\mathrm{c}}$} \\
\hline \multirow[t]{2}{*}{ A. auroguttatus } & Q. emoryi & co-evolved & $1(0-7)$ & $11(0-78)$ & This study \\
\hline & Q. hypoleucoides & co-evolved & $1(0-12)$ & $1(0-133)$ & \\
\hline $\begin{array}{l}\text { A. bilineatus (Weber), } \\
\text { twolined chestnut borer }\end{array}$ & Q. rubra, $Q$. velutina & co-evolved & $4(\mathrm{~N} / \mathrm{A})$ & $41(\mathrm{~N} / \mathrm{A})$ & {$[33]^{b}$} \\
\hline $\begin{array}{c}\text { A. biguttatus (Fabricius), } \\
\text { oak buprestid beetle }\end{array}$ & Quercus spp. & co-evolved & $\operatorname{Max}=7$ & $\operatorname{Max}=76$ & {$[34]^{\mathrm{d}}$} \\
\hline
\end{tabular}

${ }^{\mathrm{a}}$ Trees died $1-3$ y before study; ${ }^{\mathrm{b}}$ trees died $1 \mathrm{y}$ before study; ${ }^{\mathrm{c}}$ trees had died recently; ${ }^{\mathrm{d}}$ heavily infested trees.

\section{Conclusions}

Sites with co-occurring oak species that also contained populations of A. auroguttatus were scarce, which made testing the role of host species in within-tree densities of A. auroguttatus difficult. Nonetheless, in a small number of white oaks surveyed in CA and AZ, few A. auroguttatus emergence holes were recorded, whereas at some locations, significantly higher emergence hole densities were recorded for various red oaks. As an invasive species in CA, A. auroguttatus may affect the community of native borers feeding in the lower boles of oaks, although it remains unclear whether its impact will be positive or negative. One possibility is that primary attack by A auroguttatus could weaken trees and create more suitable hosts on the landscape for native borer populations. This does not seem to be the case, since we did not find much evidence of a positive correlation between emergence hole densities for $A$. auroguttatus and other borers among oak species or sites. Alternatively, by attacking apparently healthy trees and colonizing them for several successive generations, A. auroguttatus may out-compete native borers in dying trees. Both of these possibilities should be investigated further in CA and AZ oak forests.

\section{Acknowledgments}

Authors thank Lauren Walker, Mike Jones, Grayland Walter, Vanessa Lopez, Allison Bistline, and Amanda Grady for field and laboratory assistance; and Robert Haack, Josh Adkins, and Jeremy Allison for helpful comments on an earlier version of the manuscript. This work was supported by a grant from the Special Technology Development Program (\#R5-2010-02) from the USDA Forest Service, Forest Health Protection and Research and Development; by the USDA Forest Service Northern and Pacific Southwest Research Stations; by the USDA Forest Service, Forest Health Protection-Pacific Southwest Region and by the University of California-Davis. 


\section{Author Contributions}

Conceived and designed the study: LJH, TWC, MLF, RCV \& SJS. Collected and analyzed the data: LJH. Wrote the paper: LJH, TWC, MLF, RCV \& SJS.

\section{Conflicts of Interest}

The authors declare no conflict of interest.

\section{References}

1. Coleman, T.W.; Seybold, S.J. Previously unrecorded damage to oak, Quercus spp., in southern California by the goldspotted oak borer, Agrilus coxalis Waterhouse (Coleoptera: Buprestidae). Pan. Pac. Entomol. 2008, 84, 288-300.

2. Westcott, R.L. A new species of Chrysobothris Eschscholtz from Oregon and Washington, with notes on other Buprestidae (Coleoptera) occurring the United States and Canada. Zootaxa 2005, 1044, 1-15.

3. Coleman, T.W.; Seybold, S.J. Collection history and comparison of the interactions of the goldspotted oak borer, Agrilus auroguttatus Schaeffer (Coleoptera: Buprestidae), with host oaks in Southern California and Southeastern Arizona, U.S.A. Coleopts. Bull. 2011, 65, 93-108.

4. Coleman, T.W.; Lopez, V.; Rugman-Jones, P.; Stouthamer, R.; Seybold, S.J.; Reardon, R.; Hoddle, M.S. Can the destruction of California's oak woodlands be prevented? Potential for biological control of the goldspotted oak borer, Agrilus auroguttatus. BioControl 2012, 57, 211-225.

5. Haavik, L.J.; Graves, A.D.; Coleman, T.W.; Flint, M.L.; Venette, R.C.; Seybold, S.J. Suitability of native and ornamental oak species in California for Agrilus auroguttatus. Entomol. Exp. Appl. 2014, 150, 86-97.

6. Chen, Y.; Coleman, T.W.; Jones, M.I.; Flint, M.L.; Seybold, S.J. Foliar nutrients explain goldspotted oak borer, Agrilus auroguttatus Schaeffer (Coleoptera: Buprestidae), adult feeding preference among four California oak species. Entomol. Exp. Appl. 2013, 149, 57-66.

7. Keane, R.M.; Crawley, M.J. Exotic plant invasions and the enemy release hypothesis. Trends Ecol. Evol. 2002, 17, 164-170.

8. Orians, C.M.; Ward, D. Evolution of plant defenses in nonindigenous environments. Annu. Rev. Entomol. 2010, 55, 439-459.

9. Brockerhoff, E.G.; Liebhold, A.M.; Jactel, H. The ecology of forest insect invasions and advances in their management. Can. J. For. Res. 2006, 36, 263-268.

10. Lovett, G.M.; Canham, C.D.; Arthur, M.A.; Weathers, K.C.; Fitzhugh, R.D. Forest ecosystem response to exotic pests and pathogens in eastern North America. BioScience 2006, 56, 395-405.

11. Gandhi, K.J.K.; Herms, D.A. Direct and indirect effects of alien insect herbivores on ecological processes and interactions in forests of eastern North America. Biol. Invasions 2010, 12, 389-405.

12. USDA Forest Service, Forest Health Monitoring (FHM). Aerial Survey Region 5 Database. Available online: http://www.fs.usda.gov/detail/r5/forest-grasslandhealth/?cid=fsbdev3_046696/ (accessed on 5 December 2013). 
13. Coleman, T.W.; Graves, A.D.; Hoddle, M.; Heath, Z.; Chen, Y.; Flint, M.L.; Seybold, S.J. Forest stand composition and impacts associated with Agrilus auroguttatus Schaeffer (Coleoptera: Buprestidae) and Agrilus coxalis Waterhouse in oak woodlands. For. Ecol. Manage. 2012, 276, 104-117.

14. Flint, M.L.; Jones, M.I.; Coleman, T.W.; Seybold, S.J. Goldspotted oak borer. In Agriculture and Natural Resources Pest Notes Publication 74163; University of California Statewide Integrated Pest Management Program: Oakland, CA, USA, 2013; p. 7.

15. Brown, L.R.; Eads, C.O. A technical study of insects affecting the oak tree in southern California. In California Agricultural Experiment Station Bulletin 810; California Experimental Station: Berkeley, CA, USA, 1965; p. 106.

16. Furniss, R.L.; Carolin, V.M. Western Forest Insects; U.S. Department of Agriculture Forest Service: Washington, DC, USA, 1977; p. 654.

17. Swiecki, T.J.; Bernhardt, E.A. A Field Guide to Insects and Diseases of California Oaks. Gen. Tech. Rep. PSW-GTR-197; U.S. Department of Agriculture Forest Service Pacific Southwest Research Station: Albany, CA, USA, 2006; p. 151.

18. Fairweather, M.L.; McMillin, J.; Rogers, T.; Conklin, D.; Fitzgibbon, B. Field Guide to Insects and Diseases of Arizona and New Mexico Forests; U.S. Department of Agriculture Forest Service Southwestern Region MR-R3-16-3: Albuquerque, NM, USA, 2006; p. 269.

19. Haavik, L.J.; Coleman, T.W.; Flint, M.L.; Venette, R.C.; Seybold, S.J. Agrilus auroguttatus exit hole distribution on Quercus agrifolia boles and a sampling method to estimate their density on individual trees. Can. Entomol. 2012, 144, 1-12.

20. Western Regional Climate Center (WRCC). 1981-2010 Monthly Normals. Available online: http://www.wrcc.dri.edu/summary/climsmsca.html/ (accessed on 5 December 2013).

21. Pryde, P.R. San Diego: An Introduction to the Region; Kendall/Hunt Publishing Co.: Dubuque, IA, USA, 1984; p. 297.

22. U.S. Department of Agriculture Forest Service, Remote Sensing Applications Center. Fire Detection Maps. Available online: http://firemapper.sc.egov.usda.gov/activefiremaps.php?sensor= modis\&op $=$ maps\&rCode $=\mathrm{swx} /($ accessed on 5 December 2013).

23. Martin, S.C.; Reynolds, H.G. The Santa Rita Experimental Range: Your facility for research on semidesert ecosystems. J. Ariz. Acad. Sci. 1973, 8, 56-67.

24. Hishinuma, S.; Coleman, T.W.; Flint, M.L.; Seybold, S.J. Goldspotted Oak Borer Field Identification Guide; University of California Agriculture and Natural Resources Statewide Integrated Pest Management Program: Oakland, CA, USA, 2011; p. 6.

25. Fisher, W.S. A revision of the north American species of buprestid beetles belonging to the genus Agrilus. In Smithsonian Institution, United States National Museum, Bulletin 145; U.S. Govt. Print. Off.: Washington, DC, USA, 1928; p. 347.

26. Solomon, J.D. Guide to insect borers in North American broadleaf trees and shrubs. In USDA Forest Service Agriculture Handbook AH 706; U.S. Department of Agriculture Forest Service: Washington, DC, USA, 1995; p. 747.

27. R: A Language and Environment for Statistical Computing; R Foundation for Statistical Computing: Vienna, Austria, 2012. 
28. Shapiro, S.S.; Wilk, M.B. An analysis of variance test for normality (complete samples). Biometrika 1965, 52, 591-611.

29. Box, G.E.; Cox, D.R. An analysis of transformations (with discussion). J. Roy. Stat. Soc. B 1964, 26, 211-246.

30. Haack, R.A.; Benjamin, D.M.; Haack, K.D. Buprestidae, Cerambycidae, and Scolytidae associated with successive stages of Agrilus bilineatus (Coleoptera: Buprestidae) infestation of oaks in Wisconsin. Great Lakes Entomol. 1983, 16, 47-55.

31. McCullough, D.G.; Siegert, N.W. Estimating potential emerald ash borer (Coleoptera: Buprestidae) populations using ash inventory data. J. Econ. Entomol. 2007, 100, 1577-1586.

32. Akers, R.C.; Nielsen, D.G. Spatial emergence pattern of bronze birch borer, (Coleoptera: Buprestidae) from European white birch. J. Entomol. Sci. 1990, 25, 150-157.

33. Haack, R.A.; Benjamin, D.M. The biology and ecology of the twolined chestnut borer, Agrilus bilineatus (Coleoptera: Buprestidae), on oaks, Quercus spp., in Wisconsin. Can. Entomol. 1982, 114, 385-396.

34. Moraal, L.G.; Hilszczański, J. The oak buprestid beetle, Agrilus biguttatus (F.) (Col., Buprestidae), a recent factor in oak decline in Europe. J. Pest. Sci. 2000, 73, 134-138.

(C) 2014 by the authors; licensee MDPI, Basel, Switzerland. This article is an open access article distributed under the terms and conditions of the Creative Commons Attribution license (http://creativecommons.org/licenses/by/3.0/). 